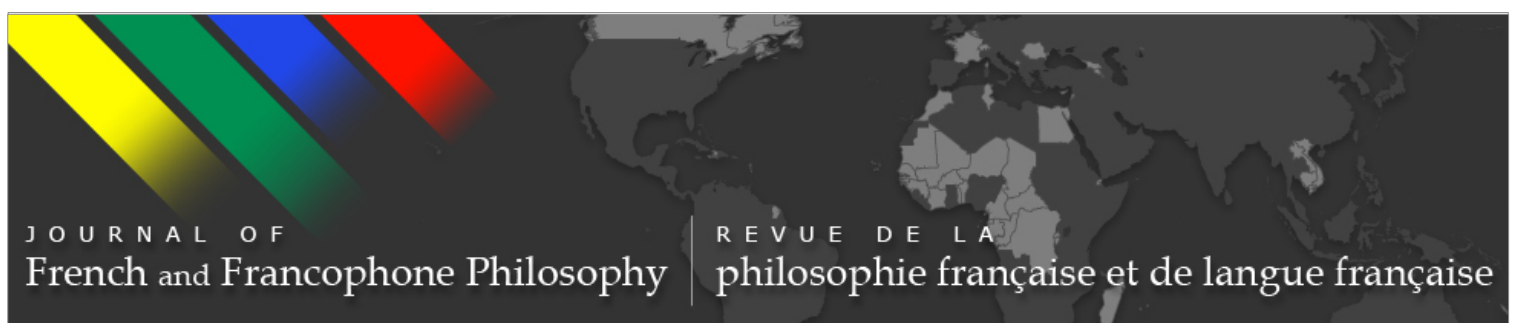

\title{
Pedagogies of Revolt, Politics of the Self
}

\section{Sarah K. Hansen}

Journal of French and Francophone Philosophy - Revue de la philosophie française et de langue française, Vol XXI, No 2 (2014) pp 56-61

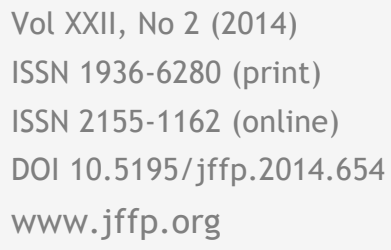

\section{(oc) BY-NG-ND}

This work is licensed under a Creative Commons Attribution-Noncommercial-No Derivative Works 3.0 United States License.

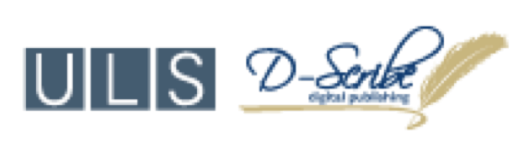

This journal is operated by the University Library System of the University of Pittsburgh as part of its D-Scribe Digital Publishing Program, and is co-sponsored by the University of Pittsburgh Press 


\section{Pedagogies of Revolt, Politics of the Self}

Sarah K. Hansen

Drexel University

Julia Kristeva's "New Forms of Revolt" touches on many familiar themes from her earlier writings. In The Sense and Nonsense of Revolt (1996) and Intimate Revolt (1997), she warns that it is no longer clear who can revolt and against whom. Today, people struggle to make meaning and form social bonds, to create and critique cultural forms. Unlike the age-old prohibition, contemporary power cannot be located because it is disseminated across manifold disciplinary mechanisms and media spectacles. According to Kristeva the "energetic pessimist," we live in a normalizing "power vacuum" in which human beings are reduced to "patrimonial individuals," to owners of genetic or physiological patrimony "free at best to channel hop." In these times, radical inner experience or "intimate revolt" is a necessary, if imperiled, mode of resistance. As she puts it in "New Forms of Revolt,"

to escape the technicians shortsighted political governance [...] having a programme is not enough. Men and women with unique, uncompromisingly questioning inner experiences are required, and this is on the condition only that they can be re-formative; men and women who know how to pass on and share the language of revolt; it is only at this cost that it can be innovative. ${ }^{1}$

For Kristeva, inner experiences are not optional nor are they wholly private. Psychic life can be the site of re-formation only because it is already politicized; intimate revolt can be innovative only when it is passed on and shared. In this essay, I'd like to reflect on the possibility of a pedagogical revolt or a revolt pedagogy, a "new form" of revolt that might be transmitted by (and beyond) Kristeva's many academic readers. There are traditions of revolt pedagogy, from Paolo Friere to Peter MacLaren, but Kristeva's emphasis on psychic life and intimate experience is distinctive and "new." ${ }^{2}$ In "New Forms of Revolt," she invites but does not specifically

Journal of French and Francophone Philosophy | Revue de la philosophie française et de langue française Vol XXII, No 2 (2014) | www.jffp.org | DOI 10.5195/jffp.2014.654 
address the question, how can educators encourage "uncompromisingly questioning inner experiences"?

Since the mid-1990s, Kristeva has written extensively on spiritual, aesthetic, psychoanalytic, and literary languages of revolt, describing intimate upheavals spurred by Christian mystical traditions, paintings of severed heads, people with disabilities, and writings from Proust to Collete. More broadly, though, intimate revolt takes place whenever we are moved to retrospective return, when troubled psyches are brought back to the constitutive borders and formative conflicts of subjectivity. If developing children must rebel in order to enter the symbolic order, abjecting the maternal body but also confronting and displacing paternal authority, then troubled adults must return to their rebellious pasts in order to renew symbolic ties. The goal of intimate revolt is therefore a pedagogical one: to offer psychic lessons and to connect with the "uniquely human" ability to represent and make meaning. Whether in a gallery or in the pages of a stirring text, revolt revisits the process of learning language and coming to know oneself and the social world. For example, in her recent book The Severed Head: Capital Visions and related Louvre exhibition Visions capitales, Kristeva shows how representations of severed heads can yield the rewards of revolt-the "singular autonomy of each as well as a renewed link with the other." $^{3}$ Although morbid, the severed head image invites artists and gallery visitors to question and reflect upon loss and separation as conditions of subjectivity. The encounter "casts one into indelible confusion but it is not impossible to compensate for that separation... by taking control [and] by concentrating on one's ability to represent." ${ }^{4}$ In this way, the Visions capitales exhibit is a pedagogical as well as an aesthetic experience. Before the canvas and in the halls of the Louvre, artists and visitors can to grieve formative losses only if they are able to develop and learn from inner experience.

While intimate revolt is educational, it is does not necessarily flourish in educational institutions, especially in the United States. In "New Forms of Revolt," Kristeva argues that our "robotizing and spectacular society damages the culture of revolt." Unfortunately, many U.S. universities have witnessed and even encouraged this decline as they struggle with diminishing state and federal investment in education. Instead of centering faculty research and student learning, schools attract student-consumers with new facilities and invest resources only where outcomes can be measured and marketed. Rather than nourishing the surprising upheavals of thought, they strive to entertain and assess students in equal measure. Kristeva gestures to these problems when she cites some hopeful examples of intimate revolt. She celebrates academics who choose-riskily- to explore values instead of data. She also shares a memory of a "Chilean student waving a Spanish translation of my writing on revolt outside his institution, which was on strike and displayed a poster that read: 'University

Journal of French and Francophone Philosophy | Revue de la philosophie française et de langue française 
in revolt,' because of drastic funding cuts to education. ${ }^{5}$ On campuses that are at once austere and spectacular, revolt most often takes place at the margins and with risks - in social protests, creative-value oriented research programs, literary or aesthetic endeavors. In fact, the revolt pedagogy of Visions capitales was a kind of experiment at institutional margins. The exhibit was part of Parti Pris ("Taking Sides" or "Biased Views"), a series at the Louvre that featured thematic shows curated by intellectuals who are not museum or art professionals. Through these guest curators, Parti Pris sought to introduce difference and conflict into a museum overtaken by the culture industry and condemned to "authoritarian sermonizing on repetitive values"; at the Louvre, "it seemed as if renovating [museum] walls was inversely proportionate to renovating its ideas." 6 To encourage intimate revolt, Parti Pris forged something that may still be possible at educational institutions or their margins_- “a critical space. A zone of frankness. A place of rupture." 7

Kristeva is hopeful about the rewards of revolt, but she acknowledges the "price of errors and dead ends." For every zone of frankness, there is another compromised in some fashion, if not by the society of the spectacle or technical ratiocination then by pseudo-rebellious nihilism. In "New Forms of Revolt," Kristeva argues that contemporary nihilism leads to stasis and fixation. The nihilist rejects old values but is "reconciled to the stability of new values. And this stability, which is illusory, turns out to be deadly and totalitarian." 8 By contrast, the person in revolt twists and turns in relentless questioning. Instead of withdrawing into faux-stable values, they are surprised and unsettled in ways that reflect the etymology of revolt. Where "revolution" has an history of intellectual associations via revolvere (to consult, to reread, to tell), revolt veers off-depending on history." ${ }^{9}$ The French semes connect it to sullying, reversal, detour, cycle, stalling, upheaval, recovery, re-assessment. Can these qualities characterize revolts at the margins of the university? I think of an installation at my own institution in which a stairwell was "hacked" to make an electronic keyboard played by one's feet. With no signage in the area, the music surprises stair-climbers, intervening in the bustle of their day and returning them of their capacity to create and make music. The hack spurs the kind of self-reflection and selfquestioning associated with revolt, but it is not impervious to the spectacle or nihilistic dead ends. Indeed, Kristeva worries whether technology is a new dogma or cult whose stable values are illusory. Although she does not address digital music or hacking, her concerns resonate in the era of the massive online open course (MOOC) and on campuses where the humanities "serve" courses for the sciences. Technology can be "deadly and totalitarian" but it can also forge "places of rupture." Technology can devalue questioning or distract us from it, or it can pose questions and inspire us to ask our own.

Journal of French and Francophone Philosophy | Revue de la philosophie française et de langue française Vol XXII, No 2 (2014) | http://www.jffp.org | DOI 10.5195/jffp.2014.654 
For Kristeva, the difference lies in loving relationships. From the earliest movements of curiosity to the questioning return of intimate revolt, love buoys. In "New Forms of Revolt," she highlights "the need to believe" as an early experience of curiosity rooted in the pre-linguistic "oceanic feeling," the period in which the borders between self and other, child and mother, are not yet established. This is the "heart of belief [...] not in the sense of a supposition, but rather that of an unshakeable certainty, a sensorial plentitude and ultimate truth." ${ }^{10}$ At the end of this period, the child separates itself from the mother with the help of the "loving father" who loves and is loved by the mother. The love relation allows the child to distinguish themselves and to change their stammering into linguistic signs. "I believed and therefore I spoke [...] Then carried by this faith that lets me hear a loving/loved outside, I burst in to questions." ${ }^{11}$ For Kristeva, loving relations support the child's turn to language. You can ask questions only if you believe in language. "You can know if and only if you believe you know." ${ }^{12}$ In adulthood, intimate revolt can renew belief, reminding the troubled psyche that meaning making is not merely a compensation for loss but also a gift, an opening onto the possibility of love and the pleasures of social connection. In educational contexts, an emphasis on loving relationships may make intimate revolt more likely. Educators can develop exercises or activities that associate the capacity to represent with the capacity to connect and share. After all, in order to believe in language and begin questioning, students must believe that there is an accepting space for love, drives, and affect in the site of meaning. Importantly, the rules and organization of an institution must be also amenable to loving connection. As a counterexample, I think of the "no excuses" pedagogy championed by Samuel Casey Carter, The Heritage Foundation and a growing number of K12 charter schools in the United States. ${ }^{13}$ The approach requires teachers to set exacting disciplinary standards and then to "sweat the small stuff," punishing students for the smallest transgressions. Since the goal is student compliance for the sake of student compliance, order for the sake of order, "no excuses" is inconsistent with revolt. Order, whether in a narrowly linguistic sense or broadly social sense, is valuable for the sake of love, connection and social bonds. An emptied order, alienated from emotions, drives, and affects, offers little comfort to despairing psyches and threatens psychic space.

Although Kristeva has written extensively about depressive social orders lacking in love, in "New Forms of Revolt" her attention actually centers on ideality syndrome, the belief that there exists an absolute satisfaction and the delinquency and turmoil that accompanies its disappointment. According to Kristeva, adolescents are especially prone to ideality but we are "all adolescents when we are enthralled by the absolute." ${ }^{14}$ Unlike the nihilist, the adolescent believes too fiercely and hopes to surpass or even abolish the parental couple. ${ }^{15}$ In the spiral of disillusionment, however, these demands collapse into nihilism yet again.

Journal of French and Francophone Philosophy | Revue de la philosophie française et de langue française Vol XXII, No 2 (2014) | http://www.jffp.org | DOI 10.5195/jffp.2014.654 
At one point, Kristeva refers to this figure as the "nihilist believer [...] necessarily nihilist because pathetically idealist." ${ }^{16}$ When reality falls short of their ideals, they lament: "I have no choice but to be angry and seek revenge with them: vandalism is what follows. [...] I have no choice but to take it out on myself: self-mutilation and self-destructive behavior follows." ${ }^{17}$ The adolescent lashes out in destructive and self-destructive ways because, while they believe, they do not believe in language. On Kristeva's view, psychoanalysis is especially attuned to ideality because of its emphasis on attentive listening. If the adolescent has their demands recognized and heard, they might begin to "metabolize their need to believe through the pleasure that comes with thinking, questioning, and analyzing." $^{18}$ In listening, the analyst offers a path away from disillusionment and disappointment to a space of loving acceptance in language. Although educators cannot hope or plan to psychoanalyze their students, the practice of loving listening should be centered in pedagogy. The phenomenon of the "flipped classroom" is one way to lift student voices, but the practice of listening must also be promoted as well, especially on the part of professors. In the face of student rebellions, professors tend to redouble authority or order in its emptiest forms. Loving listening may be a more vulnerable alternative but it is also more likely to achieve the transition to thinking, questioning, analyzing.

Kristeva herself may need to harness the power and vulnerability of loving listening when it comes to her account of French "suburban troubles." In her view, unrest at the edges of Paris, Marseilles, and other cities reflects not only the "failure of the French model of secularism" and the clash of religions but also the upsurge of "radical evil." ${ }^{19}$ It is certainly true that "the troubles" indict the secularism of Sarkozy's ban on the veil and the Islamophobic policing that the ban has emboldened. However, the charge of extreme or radical evil moves too quickly away from listening to judgment. Suburban unrest may illustrate that "following familiar disintegrations and social failures, certain people-especially adolescentssuccumb to the disease of ideality: they literally explode." ${ }^{20}$ But, whether in the suburbs or the margins of the university, these are the kind of rebellions that require the recognition of loving listening and that promise upheaval, detours, twists and turns. If the loving posture of revolt discriminates, encouraging the questioning inner experiences of some but not the questioning inner experience of others, its rewards are lost-the "singular autonomy of each as well as a renewed link with the other." In "New Forms of Revolt," Kristeva insists that we consider psychic troubles alongside social problems, even or especially when those social problems are as extreme as the suburbs. Without the lessons of intimate revolt, supported by educators but by no means limited to classrooms or campuses, we imperil both curiosity and connection. After all, "the need for connection might one day initiate another politics [...] As Albert Camus said 'I revolt, therefore we are.' Or rather, 'I revolt, therefore we are to come.'",21

Journal of French and Francophone Philosophy | Revue de la philosophie française et de langue française

Vol XXII, No 2 (2014) | http://www.jffp.org | DOI 10.5195/jffp.2014.654 
1 Julia Kristeva, "New Forms of Revolt," Journal of French and Francophone

2 See Paolo Freire, Pedagogy of the Oppressed (New York: Bloomsbury, 2000) and Peter MacLaren, Life in Schools: An Introduction to Critical Pedagogy (Boston: Allyn and Bacon, 2002).

${ }^{3}$ Kristeva, "New Forms of Revolt," 7.

${ }^{4}$ Kristeva, Severed Head: Capital Visions (New York: Columbia University Press, 2012) 6.

${ }^{5}$ Kristeva, “New Forms of Revolt," 2.

${ }^{6}$ Regis Michel, "Alibi?" in The Severed Head: Capital Visions (New York: Columbia University Press, 2012), xvii.

${ }^{7}$ Regis, xvii-xviii.

${ }^{8}$ Kristeva, “New Forms of Revolt," 5.

${ }^{9}$ Kristeva, The Sense and Nonsense of Revolt (New York: Columbia University Press, 2000), 2-4.

${ }^{10}$ Kristeva, "New Forms of Revolt," 12.

11 Kristeva, "New Forms of Revolt," 14.

12 Kristeva, "New Forms of Revolt," 14.

13 See Samuel Casey Carter, No Excuses: Lessons from 21 High Performing High Poverty Schools (Washington D.C.: The Heritage Foundations, 2000).

${ }^{14}$ Kristeva, "New Forms of Revolt," 14.

15 Kristeva, "New Forms of Revolt," 14.

${ }^{16}$ Kristeva, “New Forms of Revolt," 17.

${ }^{17}$ Kristeva, "New Forms of Revolt," 15.

18 Kristeva, "New Forms of Revolt," 16.

${ }^{19}$ Kristeva, "New Forms of Revolt," 17.

20 Kristeva, "New Forms of Revolt," 17.

${ }^{21}$ Kristeva, "New Forms of Revolt," 3. 